\title{
An evaluation of the $8^{\text {th }}$ edition of the American Joint Committee on Cancer (AJCC) staging system for retroperitoneal sarcomas using the National Cancer Data Base (NCDB): Does size matter?
}

\author{
Sarah B. Fisher, MD, Yi-Ju Chiang, MSPH, Barry W. Feig, MD, Janice N. Cormier, MD, MPH, \\ Kelly K. Hunt, MD, Keila E. Torres, MD, and Christina L. Roland, MD, MS \\ University of Texas MD Anderson Cancer Center, Department of Surgical Oncology, Houston, TX \\ USA
}

\section{Abstract}

Objectives: Retroperitoneal sarcomas (RPS) are often large at diagnosis calling into question the $7^{\text {th }}$ edition AJCC size classification of $<5 \mathrm{~cm}$ (T1) or $25 \mathrm{~cm}$ (T2). The $8^{\text {th }}$ edition expands $\mathrm{T}$ stage into 4 categories (T1: $5 \mathrm{~cm}, \mathrm{~T} 2: 5<\mathrm{x} \leq 10 \mathrm{~cm}, \mathrm{~T} 3: 10<\mathrm{x} \leq 15 \mathrm{~cm}, \mathrm{~T} 4:>15 \mathrm{~cm}$ ). We evaluated the prognostic ability of the $8^{\text {th }}$ edition using the National Cancer Database (NCDB).

Methods: Patients with RPS treated between 1998-2011 were identified from the NCDB; overall survival (OS) was compared.

Results: Of the 6,427 patients identified, 9\% had tumors $5 \mathrm{~cm}(\mathrm{n}=580), 19.4 \% 5<\mathrm{x} \leq 10 \mathrm{~cm}$ $(\mathrm{n}=1,246), 20.2 \% 10<\mathrm{x} \leq 5 \mathrm{~cm}(\mathrm{n}=1,298)$ and $47.4 \%>15 \mathrm{~cm}(\mathrm{n}=3,045)$. With the $8^{\text {th }}$ edition, stage II patients (G2/3 $5 \mathrm{~cm}$ ) have a similar OS to stage IIIA patients (G2/3 $5 \mathrm{~cm}<\mathrm{x} \leq 10 \mathrm{~cm})$, and patients with larger tumors (stage IIIB, G2/3>10cm) show a decrease in OS. Tumor size as a continuous variable had a modest effect on survival (HR 1.004, $\mathrm{p}=0.04$ ). On multivariate analysis, higher Tstage was associated with decreased OS (T4 HR 1.3, p<0.001) but high grade and incomplete resection $(\mathrm{R} 2)$ were stronger prognostic factors. The c-index for both editions were similar (80.13 8 th vs 80.087 th).

Conclusions: The $8^{\text {th }}$ edition AJCC staging system for retroperitoneal sarcoma incorporates larger tumor size parameters that better characterize most patients, but tumor size alone is only a modest predictor of outcome.

\section{Keywords}

retroperitoneal sarcoma; staging; survival; AJCC $8^{\text {th }}$ edition

Corresponding Author: Christina L. Roland (CLRoland@mdanderson.org), 1515 Holcombe Boulevard, Houston, TX 77030, Phone: 713-792-6161.

Conflicts of Interest:

No conflict of interest disclosures. 


\section{Introduction}

Soft tissue sarcomas comprise a rare and heterogeneous group of cancers, with approximately 13,040 new cases per year and more than 50 different histologic subtypes.[1] Of these, only $10-15 \%$ arise in the retroperitoneum, which makes study of retroperitoneal sarcoma (RPS) and the development of a meaningful staging system difficult. Since 1977 the American Joint Committee on Cancer (AJCC) has used available evidence-based literature to construct staging systems for many cancers. In addition to the three variables that comprise the foundation of most cancer staging systems - tumor size (T), nodal status $(\mathrm{N})$, and distant metastases $(\mathrm{M})$ - sarcoma staging has included grade $(\mathrm{G})$ and tumor depth (superficial/deep) since its inception in 1992.[2] Yet even with the incorporation of these additional variables, previous staging systems for sarcoma have been found lacking, and their application to RPS in particular has been questioned.[3-7] Previous staging criteria were based largely on data that included a majority of patients with extremity or trunk sarcomas, which have a tumor biology distinct from RPS.[8,9] Additionally, the $\mathrm{T}$ and $\mathrm{N}$ categories may be less meaningful for RPS, as nodal disease is prognostic but rare $[3,10]$ and tumor size at the time of diagnosis is often larger than historical staging parameters.[4,6,1015]

The recently released AJCC $8^{\text {th }}$ edition staging manual addresses some of these concerns. The $8^{\text {th }}$ edition creates a separate staging system specific to the retroperitoneal location, appropriately removes the superficial/deep category formerly used for tumors in nonretroperitoneal locations, and adds two additional $\mathrm{T}$ categories to characterize larger tumors. [16] The previous T1 category is preserved ( $5 \mathrm{~cm}$ ), tumors that are greater than $5 \mathrm{~cm}$ but less than or equal to $10 \mathrm{~cm}$ are now $\mathrm{T} 2$, tumors that are greater than $10 \mathrm{~cm}$ but less than or equal to $15 \mathrm{~cm}$ are now T3, and tumors that are greater than $15 \mathrm{~cm}$ are T4. These changes result in reclassification of patients from the IIB/III groups in the $7^{\text {th }}$ edition to the IIIA/IIIB groups in the $8^{\text {th }}$ edition (Figure 1A-C). The value of the updated AJCC staging classification is unclear.

Recently an analysis using the Surveillance, Epidemiology, and End Results (SEER) database found the predictive accuracy and concordance indices of the AJCC $8^{\text {th }}$ edition staging system to be lower than the previous version, with tumor size having only a limited effect on overall survival (OS) after accounting for other prognostic factors.[17] In contrast to SEER, which is population based, the National Cancer Database (NCDB) collects hospital-based registry data specifically from Commission on Cancer accredited facilities, thus representing an assessment of practice patterns amongst institutions with a specific focus on cancer medicine. $[18,19]$ In the current study, we use the NCDB to evaluate the prognostic value of the AJCC $8^{\text {th }}$ edition staging system for RPS.

\section{Materials and Methods}

The NCDB Participant User File for sarcoma was queried for patients age 18 years or older with retroperitoneal tumors treated at the reporting facility between January 1, 1998 and December 31, 2011, using the International Classification of Disease for Oncology ( $3^{\text {rd }} \mathrm{ed}$ ) topography code $\mathrm{C} 480$. The histologic subtypes were reviewed and the following histologic 
subtypes were excluded: non-sarcomatous or mixed histologies and dermatofibrosarcoma protuberans. Patients with less than 90 days of follow-up, significant gaps in their clinical data, and/or inadequate information for tumor, node, and metastasis (TNM) staging for classification according to the AJCC $7^{\text {th }}$ or $8^{\text {th }}$ edition staging systems were also excluded. Patients with stage T0, tumor size recorded as " 0 ," or discordant classification between pathologic node status and number of nodes assessed (i.e. pathologic node positive and number of nodes assessed $=0$ ) were excluded. Patients with localized disease who did not undergo surgery were excluded (Supplemental Figure).

Kaplan-Meier survival curves and Cox proportional hazard models were used to evaluate OS. Univariate and multivariate analyses were performed to identify factors associated with OS. Concordance indices (C-index) were calculated to evaluate the discriminatory power of the $7^{\text {th }}$ and $8^{\text {th }}$ AJCC staging editions. Analyses were performed using SAS 9.4 (Cary, NC), with statistical significance defined at $\mathrm{p}<0.05$.

\section{Results}

\section{Patient Characteristics}

Table 1 demonstrates the demographics and clinical characteristics of the 6,427 patients with retroperitoneal sarcoma in the study. Liposarcoma was the most common histology ( $n=3,304$ $51.4 \%)$, followed by leiomyosarcoma $(\mathrm{n}=1,89229.4 \%)$, and sarcoma not otherwise specified (NOS, $\mathrm{n}=354,5.5 \%)$. The median tumor size was $15 \mathrm{~cm}($ range 3-99 $\mathrm{cm}$ ) with $9 \%$ of patients having tumors $5 \mathrm{~cm}(\mathrm{n}=580), 19.4 \%$ with tumors $5<\mathrm{x} \leq 10 \mathrm{~cm}(\mathrm{n}=1,246), 20.2 \%$ with tumors $10<\mathrm{x} \leq 15 \mathrm{~cm}(\mathrm{n}=1,298)$ and $47.4 \%$ with tumors $>15 \mathrm{~cm}(\mathrm{n}=3,045)$.

Most patients were treated with surgical resection (radical resection $n=3,082,48.0 \%$; local resection $\mathrm{n}=2,181,33.9 \%$; debulking $\mathrm{n}=309,4.8 \%$; unknown surgical resection $\mathrm{n}=265$, $4.1 \%)$. A small subset of patients received chemotherapy $(\mathrm{n}=1,146,17.8 \%)$ and/or radiation therapy ( $\mathrm{n}=1,769,27.5 \%)$. The majority of patients underwent an R0/R1 resection ( $\mathrm{n}=3,956$, $61.4 \%$ ); data on concomitant organ resection were not available. As expected, surgical lymph node assessment was uncommon, with $21.3 \%(\mathrm{n}=1,372)$ undergoing pathologic assessment of at least one node.

\section{Staging}

Patients with intermediate grade tumors greater than $5 \mathrm{~cm}$ in size who were previously classified as stage IIB in the $7^{\text {th }}$ edition $(\mathrm{n}=636)$ were redistributed into either stage IIIA $(\mathrm{n}=186,29.2 \%)$ or stage IIIB $(\mathrm{n}=450,70.8 \%)$ according to the $8^{\text {th }}$ edition guidelines depending on tumor size (Figure 1 A-C). Similarly, patients with high grade tumors greater than $5 \mathrm{~cm}$ who were previously classified as stage III in the $7^{\text {th }}$ edition $(\mathrm{n}=2,129)$ were redistributed into either stage IIIA $(n=422,19.8 \%)$ or stage IIIB $(n=1,707,80.2 \%$, Figure 1 A-C).

\section{Overall Survival}

Median follow up for the cohort was 36.6 months. Overall survival for both the $7^{\text {th }}$ and the $8^{\text {th }}$ staging editions is shown in Figure $2 A \&$ B. In the $7^{\text {th }}$ edition, patients with stage IIB 
disease (larger, intermediate grade tumors) had significantly better OS than patients with stage IIA (small intermediate or high grade tumors) disease $(\mathrm{p}<0.001$, Table 2$)$. With the $8^{\text {th }}$ edition, patients with stage II disease (previously $7^{\text {th }}$ edition IIA, small intermediate or high grade tumors) have a similar OS to stage IIIA patients (intermediate or high grade tumors $5 \mathrm{~cm}<\mathrm{x} \leq 10 \mathrm{~cm}$ ), whereas patients with larger tumors of similar grade (stage IIIB, intermediate or high grade $>10 \mathrm{~cm}$ ) show a decrease in OS (Table 2). Stage IIIB also included 106 patients with nodal disease; there was no difference in OS within stage IIIB when stratified by nodal status $(\mathrm{p}=0.931)$. The $\mathrm{c}$-index for both editions were similar $\left(7^{\text {th }}\right.$ edition: $80.1,95 \%$ CI $77.3-82.7$; $8^{\text {th }}$ edition: $80.1,95 \%$ CI $77.3-82.8$ ).

\section{Role of T stage}

In the $7^{\text {th }}$ edition, patients with $\mathrm{T} 1$ and $\mathrm{T} 2$ disease had a 5 -year OS of $57.5 \%$ and $52.4 \%$, respectively ( $\mathrm{p}<0.001)$. In the $8^{\text {th }}$ edition, 5 -year OS based on T stage alone was $57.5 \%$, $55.1 \%, 51.8 \%$, and $51.5 \%$ for $\mathrm{T} 1, \mathrm{~T} 2, \mathrm{~T} 3$, and $\mathrm{T} 4$ patients, respectively, $\mathrm{p}=0.007$ (Figure 2C $\& \mathrm{D})$.

When analyzed as a continuous variable amongst patients with stage I-III disease, increasing tumor size was significantly associated with decreased OS, although the HR for each centimeter increase was small (HR=1.004, 95\% CI: 1.000-1.007, $\mathrm{p}=0.04)$. When dichotomized at $5 \mathrm{~cm}$ intervals for tumors up to $25 \mathrm{~cm}$, a significant effect on OS for each size group was identified starting with tumors $>10 \mathrm{~cm}$ (Supplemental Table 1).

\section{Univariate and Multivariate Analyses}

Amongst patients with localized disease (stages I-III), univariate analysis identified older age, male sex, government insurance status, treatment at a non-academic facility, debulking resection, incomplete surgical resection, higher $\mathrm{T}$ stage, higher grade, presence of nodal disease, chemotherapy administration, and lack of radiation therapy were factors associated with poorer OS. In a multivariate model which included only patients with complete information $(n=3,681)$, T stage remained a weak prognostic factor for OS with a significant difference noted between patients with T4 versus T1 tumors (HR 1.3, 95\% CI 1.08-1.57, $\mathrm{p}<0.001$, Table 3). A significant association with OS was not observed for patients with $\mathrm{T} 2$ or T3 tumors as compared to T1 tumors. High tumor grade, incomplete (R2) resection and debulking procedures were associated with the highest HRs for death (Table 3).

For patients with metastatic disease $(n=749)$ increasing age, male sex, government insurance status, treatment at a non-academic facility, and high grade tumors were associated with poorer OS, whereas selection for surgery was associated with better OS (Supplemental Table 2).

\section{Discussion}

The current study uses the NCDB to evaluate the performance of the $8^{\text {th }}$ edition AJCC staging manual for RPS. Our results suggest that while adding additional $\mathrm{T}$ stage categories may more accurately characterize tumor size, the overall outcome with respect to the prognostication for OS among these subgroups is minimal. Other clinicopathologic factors 
such as tumor grade and ability to achieve a complete surgical resection are associated with greater differences in patient survival compared to tumor size.

Historically, knowledge regarding the prognostic factors and outcomes for patients with RPS was based on retrospective analyses from single, high-volume institutions.[4,11,20-22] More recently, researchers have utilized regional[23] or national databases, [6,10,24-28] or formed multi-institutional working groups, $[15,29]$ with some spanning multiple countries, [14] to define factors that influence outcomes of patients with RPS. The results with respect to the role of tumor size as a prognostic factor are conflicting. In one of the largest single institution series $(\mathrm{n}=500)$, tumor size $>10 \mathrm{~cm}$ was associated with decreased OS on multivariate analysis in patients with primary RPS (HR=1.7 95\% CI: $1.1-2.7, \mathrm{p}=0.02)$ but was not associated with distant metastasis free survival or locoregional recurrence.[20] Others have supported using $10 \mathrm{~cm}$ as a prognostic cutpoint,[10] or shown a similar relationship between OS and tumor size using $15 \mathrm{~cm}$ as a cutpoint.[4,25,30] Many investigators, however, have not found a relationship between tumor size and outcome at all. [13,15,20,31-33]. In a Surveillance, Epidemiology, and End Results (SEER) analysis spanning 17 years and including 1,365 patients, Nathan et al.[6] was unable to identify an association between tumor size and OS when using tumor size either as a continuous variable or dichotomized at various cutpoints, including $20 \mathrm{~cm}, 10 \mathrm{~cm}$, as well as the AJCC $7^{\text {th }}$ edition cutpoint of $5 \mathrm{~cm}$. Similarly, Berger et al.[26] did not identify a relationship between tumor size and OS in their analysis of 2,762 patients included in the National Cancer Database treated between 2004 and 2013. Our findings suggest that tumor size, categorized by $\mathrm{T}$ stage, is at most a modest prognostic factor for OS, with other variables including high grade, incomplete resection ( $\mathrm{R} 2$ margin), and presence of nodal disease having a greater impact on OS, which are well accepted within the literature as negative prognostic factors.[10,12,20,21,27,33,34]

One potential explanation for the conflicting data pertaining to tumor size as a prognostic factor is the possibility that the effect is bimodal - i.e. tumor size may be prognostic up to a certain point, but after that larger tumors may demonstrate indolent biology and behavior. In an analysis of 192 patients, Ardoino et al.[11] found that the relative hazard for death after resection of primary nonmetastatic RPS increased with tumor size up to $25 \mathrm{~cm}$, and decreased thereafter, similar to the findings in the current study. This relationship is also captured in two RPS specific nomograms, in which increasing tumor size is associated with a worse prognosis up to $30 \mathrm{~cm}$, and then reverses for tumors larger than $30 \mathrm{~cm} .[7,35]$ The current AJCC $8^{\text {th }}$ edition staging system is not structured to capture this relationship.

While one advantage of an NCDB study is that it represents practice patterns across multiple institutions with cancer-specific standards, the large registry-based nature also results in inevitable heterogeneity of data despite rigorous quality controls. The rarity of RPS, presence of multiple histologic subtypes and grading schema, changes in usage of diagnostic terms over time, and impracticality of central pathologic review when using a large registry further contribute to variability and risk of diagnostic error.[36] Therefore, the current work is limited in its ability to evaluate prognosis based on specific histologic subtype. Large volume single institution or multiple institution studies with central pathologic review are 
better suited to evaluate the role of histology on prognosis, and have been used to develop sarcoma specific nomograms incorporating the histologic subtype.[4,7,11,35]

In the $8^{\text {th }}$ edition, the AJCC recognized the need for more personalized prognostic tools across all disease sites and encouraged the use of well validated nomograms. Of the four currently available nomograms specific to RPS, $[4,7,11,35]$ the AJCC endorsed a model designed by Gronchi et al.[7] for patients with RPS undergoing curative intent resection and externally validated in two separate studies.[37,38] The model incorporates tumor size and grade, and also takes into account factors not captured by the AJCC staging manual: seven histologic categories, patient age, multifocality, and extent of resection. Nomograms are exceedingly useful tools for calculating individual patient risk, but cannot replace the need for a common language that can accurately and efficiently describe and compare groups of patients.

\section{Conclusions}

The creation of a specific staging system for retroperitoneal sarcoma and the addition of larger $\mathrm{T}$ stages is a move towards more accurate description, but the discriminatory power of the AJCC $8^{\text {th }}$ edition staging manual for retroperitoneal sarcoma remains limited. Future staging modifications within the confines of the TNMG system should consider larger T size categories and account for the possibility of a bimodal effect of tumor size on survival.

\section{Supplementary Material}

Refer to Web version on PubMed Central for supplementary material.

\section{Acknowledgments}

Sources of Funding:

Funded in part by K12 CA088084 - Paul Calabresi Clinical Oncology Award and P30 CA016672 - Cancer Center Support (CORE) Grant. Presented as an oral presentation at the Society of Surgical Oncology Annual Cancer Symposium March 21-24, 2018, Chicago, IL.

\section{REFERENCES}

1. Siegel RL, Miller KD, Jemal A: Cancer statistics, 2018. CA: a cancer journal for clinicians 2018;68:7-30. [PubMed: 29313949]

2. Kotilingam D, Lev DC, Lazar AJ, Pollock RE: Staging soft tissue sarcoma: evolution and change. CA: a cancer journal for clinicians 2006;56:282-291; quiz 314-285. [PubMed: 17005597]

3. van Dalen T, Hennipman A, Van Coevorden F, et al.: Evaluation of a clinically applicable postsurgical classification system for primary retroperitoneal soft-tissue sarcoma. Annals of surgical oncology 2004;11:483-490. [PubMed: 15078637]

4. Anaya DA, Lahat G, Wang X, et al.: Postoperative nomogram for survival of patients with retroperitoneal sarcoma treated with curative intent. Annals of oncology : official journal of the European Society for Medical Oncology 2010;21:397-402. [PubMed: 19622598]

5. Lahat G, Tuvin D, Wei C, et al.: New perspectives for staging and prognosis in soft tissue sarcoma. Annals of surgical oncology 2008;15:2739-2748. [PubMed: 18521685]

6. Nathan H, Raut CP, Thornton K, et al.: Predictors of survival after resection of retroperitoneal sarcoma: a population-based analysis and critical appraisal of the AJCC staging system. Annals of surgery 2009;250:970-976. [PubMed: 19644351] 
7. Gronchi A, Miceli R, Shurell E, et al.: Outcome prediction in primary resected retroperitoneal soft tissue sarcoma: histology-specific overall survival and disease-free survival nomograms built on major sarcoma center data sets. Journal of clinical oncology : official journal of the American Society of Clinical Oncology 2013;31:1649-1655. [PubMed: 23530096]

8. Pisters PW, Leung DH, Woodruff J, et al.: Analysis of prognostic factors in 1,041 patients with localized soft tissue sarcomas of the extremities. Journal of clinical oncology : official journal of the American Society of Clinical Oncology 1996;14:1679-1689. [PubMed: 8622088]

9. Brennan MF: Staging of soft tissue sarcoma: what is new? Annals of surgical oncology 2008;15:2643. [PubMed: 18685895]

10. Giuliano K, Nagarajan N, Canner JK, et al.: Predictors of improved survival for patients with retroperitoneal sarcoma. Surgery 2016;160:1628-1635. [PubMed: 27495850]

11. Ardoino I, Miceli R, Berselli M, et al.: Histology-specific nomogram for primary retroperitoneal soft tissue sarcoma. Cancer 2010;116:2429-2436. [PubMed: 20209615]

12. Ballo MT, Zagars GK, Pollock RE, et al.: Retroperitoneal soft tissue sarcoma: an analysis of radiation and surgical treatment. International journal of radiation oncology, biology, physics 2007;67:158-163.

13. Gilbeau L, Kantor G, Stoeckle E, et al.: Surgical resection and radiotherapy for primary retroperitoneal soft tissue sarcoma. Radiotherapy and oncology : journal of the European Society for Therapeutic Radiology and Oncology 2002;65:137-143. [PubMed: 12464441]

14. Gronchi A, Strauss DC, Miceli R, et al.: Variability in Patterns of Recurrence After Resection of Primary Retroperitoneal Sarcoma (RPS): A Report on 1007 Patients From the Multi-institutional Collaborative RPS Working Group. Annals of surgery 2016;263:1002-1009. [PubMed: 26727100]

15. Stoeckle E, Coindre JM, Bonvalot S, et al.: Prognostic factors in retroperitoneal sarcoma: a multivariate analysis of a series of 165 patients of the French Cancer Center Federation Sarcoma Group. Cancer 2001;92:359-368. [PubMed: 11466691]

16. “AJCC 8th Edition Cancer Staging Manual.” Springer International Publishing, 2017.

17. Cates JMM: Performance Analysis of the American Joint Committee on Cancer 8th Edition Staging System for Retroperitoneal Sarcoma and Development of a New Staging Algorithm for Sarcoma-Specific Survival. Annals of surgical oncology 2017;24:3880-3887. [PubMed: 29058143]

18. National Cancer Database In, 2018.

19. Mohanty S, Bilimoria KY: Comparing national cancer registries: The National Cancer Data Base (NCDB) and the Surveillance, Epidemiology, and End Results (SEER) program. Journal of surgical oncology 2014;109:629-630. [PubMed: 24464362]

20. Lewis JJ, Leung D, Woodruff JM, Brennan MF: Retroperitoneal soft-tissue sarcoma: analysis of 500 patients treated and followed at a single institution. Annals of surgery 1998;228:355-365. [PubMed: 9742918]

21. Gronchi A, Lo Vullo S, Fiore M, et al.: Aggressive surgical policies in a retrospectively reviewed single-institution case series of retroperitoneal soft tissue sarcoma patients. Journal of clinical oncology : official journal of the American Society of Clinical Oncology 2009;27:24-30. [PubMed: 19047283]

22. Bonvalot S, Rivoire M, Castaing M, et al.: Primary retroperitoneal sarcomas: a multivariate analysis of surgical factors associated with local control. Journal of clinical oncology : official journal of the American Society of Clinical Oncology 2009;27:31-37. [PubMed: 19047280]

23. Gutierrez JC, Perez EA, Franceschi D, et al.: Outcomes for soft-tissue sarcoma in 8249 cases from a large state cancer registry. The Journal of surgical research 2007;141:105-114. [PubMed: 17512548]

24. Maurice MJ, Yih JM, Ammori JB, Abouassaly R: Predictors of surgical quality for retroperitoneal sarcoma: Volume matters. Journal of surgical oncology 2017;116:766-774. [PubMed: 28608360]

25. Stahl JM, Corso CD, Park HS, et al.: The effect of microscopic margin status on survival in adult retroperitoneal soft tissue sarcomas. European journal of surgical oncology : the journal of the European Society of Surgical Oncology and the British Association of Surgical Oncology 2017;43:168-174. 
26. Berger NG, Silva JP, Mogal H, et al.: Overall survival after resection of retroperitoneal sarcoma at academic cancer centers versus community cancer centers: An analysis of the National Cancer Data Base. Surgery 2017.

27. Tseng W, Martinez SR, Tamurian RM, et al.: Histologic type predicts survival in patients with retroperitoneal soft tissue sarcoma. The Journal of surgical research 2012;172:123-130. [PubMed: 20869082]

28. van Dalen T, Plooij JM, van Coevorden F, et al.: Long-term prognosis of primary retroperitoneal soft tissue sarcoma. European journal of surgical oncology : the journal of the European Society of Surgical Oncology and the British Association of Surgical Oncology 2007;33:234-238.

29. Pawlik TM, Pisters PW, Mikula L, et al.: Long-term results of two prospective trials of preoperative external beam radiotherapy for localized intermediate- or high-grade retroperitoneal soft tissue sarcoma. Annals of surgical oncology 2006;13:508-517. [PubMed: 16491338]

30. El-Bared N, Taussky D, Mehiri S, et al.: Preoperative intensity modulated radiation therapy for retroperitoneal sarcoma. Technology in cancer research \& treatment 2014;13:211-216. [PubMed: 23919397]

31. Heslin MJ, Lewis JJ, Nadler E, et al.: Prognostic factors associated with long-term survival for retroperitoneal sarcoma: implications for management. Journal of clinical oncology : official journal of the American Society of Clinical Oncology 1997;15:2832-2839. [PubMed: 9256126]

32. Gronchi A, Casali PG, Fiore M, et al.: Retroperitoneal soft tissue sarcomas: patterns of recurrence in 167 patients treated at a single institution. Cancer 2004;100:2448-2455. [PubMed: 15160351]

33. Abdelfatah E, Guzzetta AA, Nagarajan N, et al.: Long-term outcomes in treatment of retroperitoneal sarcomas: A 15 year single-institution evaluation of prognostic features. Journal of surgical oncology 2016;114:56-64. [PubMed: 27076350]

34. Anaya DA, Lahat G, Wang X, et al.: Establishing prognosis in retroperitoneal sarcoma: a new histology-based paradigm. Annals of surgical oncology 2009;16:667-675. [PubMed: 19101765]

35. Tan MC, Brennan MF, Kuk D, et al.: Histology-based Classification Predicts Pattern of Recurrence and Improves Risk Stratification in Primary Retroperitoneal Sarcoma. Annals of surgery 2016;263:593-600. [PubMed: 25915910]

36. Arbiser ZK, Folpe AL, Weiss SW: Consultative (expert) second opinions in soft tissue pathology. Analysis of problem-prone diagnostic situations. American journal of clinical pathology 2001;116:473-476. [PubMed: 11601130]

37. Raut CP, Miceli R, Strauss DC, et al.: External validation of a multi-institutional retroperitoneal sarcoma nomogram. Cancer 2016;122:1417-1424. [PubMed: 26916507]

38. Chou YS, Liu CY, Chang YH, et al.: Prognostic factors of primary resected retroperitoneal soft tissue sarcoma: Analysis from a single asian tertiary center and external validation of gronchi's nomogram. Journal of surgical oncology 2016;113:355-360. [PubMed: 26749009] 
A

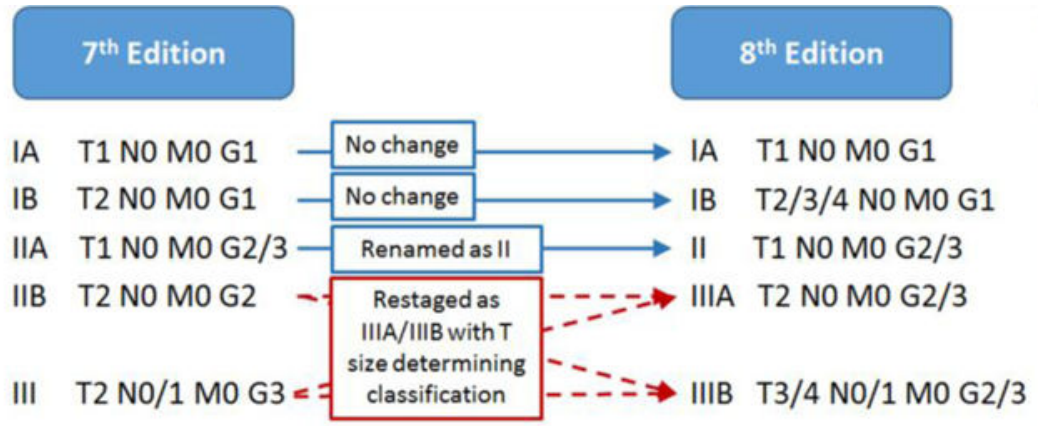

B

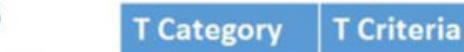

Primary cannot be assessed

No evidence of primary

$\leq 5 \mathrm{~cm}$

$>5 \mathrm{~cm}$ and $\leq 10 \mathrm{~cm}$

$>10 \mathrm{~cm}$ and $\leq 15 \mathrm{~cm}$

$>15$

IV $\mathrm{I}_{\text {anv }} \mathrm{NO} / 1 \mathrm{M} 1 \mathrm{G}_{\underline{a n v}} \underset{\text { No change }}{\longrightarrow} \mathrm{IV} \mathrm{T}_{\text {anv }} \mathrm{NO} / 1 \mathrm{M} 1 \mathrm{G}_{\underline{a n v}}$

C

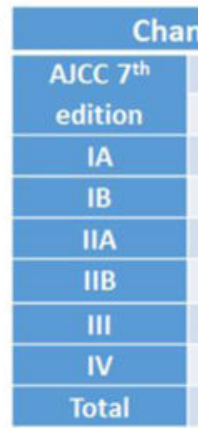
Changes in

Figure 1:

(A) Schema of the changes between the $7^{\text {th }}$ and $8^{\text {th }}$ editions of the American Joint Committee on Cancer staging systems for soft tissue sarcoma of the retroperitoneum, with (B) the updated $\mathrm{T}$ definitions (in red), and (C) the resulting changes in stages IIB/III (outlined) within the NCDB study population 

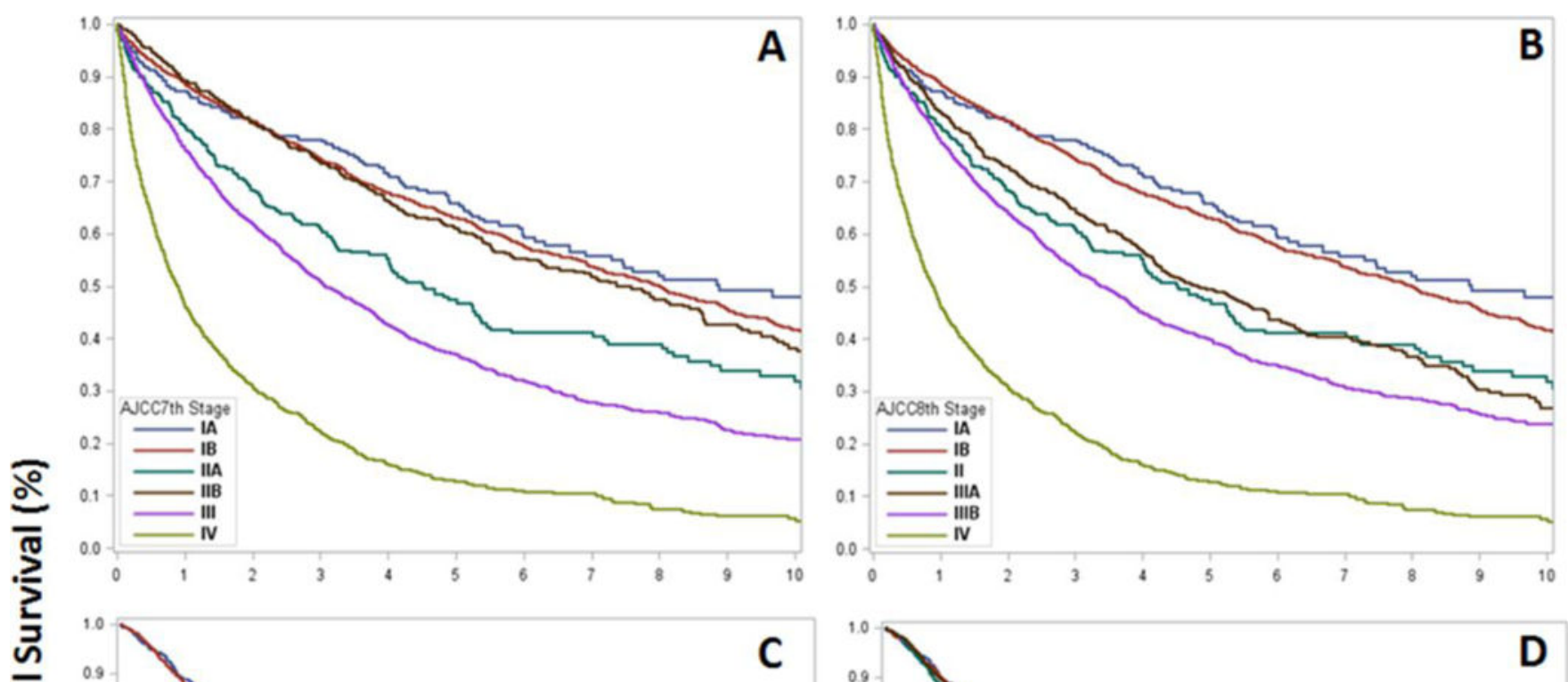

Time (years)

Figure 2:

Overall survival by stage according to the AJCC $7^{\text {th }}$ edition (A) and the $8^{\text {th }}$ edition (B); stratified by $\mathrm{T}$ stage in the AJCC $7^{\text {th }}$ edition (C) and $8^{\text {th }}$ edition (D) 
Table 1:

Demographic and Clinical Characteristics of Patients with Retroperitoneal Sarcoma in the National Cancer Database $(n=6,427)$

\begin{tabular}{|c|c|}
\hline & $\begin{array}{l}\text { n }(\%) \text { or } \\
\text { median (range) }\end{array}$ \\
\hline Age (years) & $62(18-90)$ \\
\hline Male sex & $3,013(46.9)$ \\
\hline $\begin{array}{l}\text { Race } \\
\text { White } \\
\text { Black } \\
\text { Hispanic } \\
\text { Asian } \\
\text { Other/unknown }\end{array}$ & $\begin{array}{l}5,052(78.6) \\
641(10.0) \\
400(6.2) \\
286(4.5) \\
48(0.8)\end{array}$ \\
\hline $\begin{array}{c}\text { Charlson-Deyo Comorbidity Score } \\
0 \\
1 \\
2\end{array}$ & $\begin{array}{l}3,529(79.0) \\
745(16.7) \\
191(4.3)\end{array}$ \\
\hline $\begin{array}{l}\text { Treatment Facility } \\
\text { Community Cancer Program } \\
\text { Comprehensive Community Cancer } \\
\text { Program } \\
\text { Academic/Research Program } \\
\text { Other }\end{array}$ & $\begin{array}{l}384(6.0) \\
2,441(38.0) \\
3,594(55.9) \\
8(0.1)\end{array}$ \\
\hline Tumor size (cm) & $15(3-99)$ \\
\hline $\begin{array}{l}\text { Tumor Stage } \\
7^{\text {th }} \& 8^{\text {th }} \text { Ed. T1 }(5 \mathrm{~cm}) \\
7^{\text {th }} E d . T 2(>5 \mathrm{~cm}) \\
8^{\text {th }} E d . T 2(5 \mathrm{~cm}>x \geq 10 \mathrm{~cm}) \\
8^{\text {th }} \text { Ed. T3 }(10 \mathrm{~cm}>x \geq 15 \mathrm{~cm}) \\
8^{\text {th }} \text { Ed. T4 }(>15 \mathrm{~cm}) \\
\text { Unknown }\end{array}$ & $\begin{array}{l}580(9.0)^{*} \\
5,589(87.0) \\
1,246(19.4) \\
1,298(20.2) \\
3,045(47.4) \\
258(4.0)\end{array}$ \\
\hline Nodal disease & $222(3.5 \%)^{* *}$ \\
\hline Metastatic disease & $1,023(15.9)$ \\
\hline $\begin{array}{l}\text { Grade } \\
\text { High (G3 or high-GX) } \\
\text { Intermediate }(\mathrm{G} 2) \\
\text { Low }(\mathrm{G} 1, \text { low-GX, or NOS) }\end{array}$ & $\begin{array}{l}2,851(44.4) \\
816(12.7) \\
2,760(42.9)\end{array}$ \\
\hline $\begin{array}{l}\text { Resection Margins } \\
\text { R0/R1 } \\
\text { R2 } \\
\text { Metastatic (No surgery on primary) } \\
\text { Unknown }\end{array}$ & $\begin{array}{l}3,956(61.4) \\
216(3.4) \\
590(9.2) \\
1,665(26.0)\end{array}$ \\
\hline
\end{tabular}

Ed.: edition; NOS: not otherwise specified; R1: microscopic positive margin; R2: gross positive margin

Percent total refers to the total within the respective $7^{\text {th }}$ or $8^{\text {th }}$ edition staging system, with $4.0 \%$ unknown in both

*** Includes pathologic node positive $(n=141)$ and clinically node positive $(n=81)$ 
Table 2:

Cox proportional hazards model for risk of death stratified by stage according to the AJCC $7^{\text {th }}$ and $8^{\text {th }}$ editions $(n=6,427)$

\begin{tabular}{|c|c|c|c|c|c|c|}
\hline & Stage & $\mathbf{n}$ & $\begin{array}{l}\text { Hazard } \\
\text { Ratio for } \\
\text { Death }\end{array}$ & & $\begin{array}{c}95 \% \\
\text { CI }\end{array}$ & $\begin{array}{c}\text { 5-year Overall } \\
\text { Survival }(\%)\end{array}$ \\
\hline \multirow{6}{*}{$\begin{array}{l}\text { AJCC 7th } \\
\text { Edition }\end{array}$} & IA & 240 & reference & & & 65.87 \\
\hline & IB & 2,143 & 1.19 & 0.94 & 1.50 & 63.03 \\
\hline & IIA & 256 & 1.89 & 1.42 & 2.51 & 47.26 \\
\hline & IIB & 636 & 1.40 & 1.09 & 1.81 & 60.94 \\
\hline & III & 2,129 & 2.68 & 2.12 & 3.38 & 36.97 \\
\hline & IV & 1,023 & 7.52 & 5.94 & 9.52 & 12.66 \\
\hline \multirow{6}{*}{$\begin{array}{l}\text { AJCC 8 } \\
\text { Edition }\end{array}$} & IA & 240 & reference & & & 65.87 \\
\hline & IB & 2,143 & 1.19 & 0.94 & 1.50 & 63.03 \\
\hline & II & 256 & 1.88 & 1.42 & 2.51 & 47.26 \\
\hline & IIIA & 608 & 1.84 & 1.43 & 2.37 & 49.46 \\
\hline & IIIB & 2,157 & 2.47 & 1.96 & 3.12 & 39.92 \\
\hline & IV & 1,023 & 7.49 & 5.92 & 9.48 & 12.66 \\
\hline
\end{tabular}

CI: Confidence interval; AJCC: American Joint Committee on Cancer 
Table 3:

Prognostic factors associated with impaired overall survival in patients with stage I-III retroperitoneal sarcoma $\left(\mathrm{n}=3,681^{*}\right)$

\begin{tabular}{|c|c|c|c|c|}
\hline Prognostic Factor & HR & $95 \%$ & CI & p-value \\
\hline Age (years) & 1.02 & 1.02 & 1.03 & $<0.001$ \\
\hline Female sex & 0.83 & 0.75 & 0.92 & $<0.001$ \\
\hline $\begin{array}{l}\text { Insurance status } \\
\text { Private } \\
\text { Other government } \\
\text { Medicaid } \\
\text { Medicare } \\
\text { Uninsured }\end{array}$ & $\begin{array}{l}\text { REF } \\
0.68 \\
1.40 \\
1.28 \\
1.64\end{array}$ & $\begin{array}{l}0.36 \\
1.11 \\
1.11 \\
1.18\end{array}$ & $\begin{array}{l}1.27 \\
1.78 \\
1.47 \\
2.27\end{array}$ & $<0.001$ \\
\hline $\begin{array}{l}\text { Surgery type } \\
\text { Radical } \\
\text { Local } \\
\text { Debulking } \\
\text { Resection, type unknown }\end{array}$ & $\begin{array}{l}\text { REF } \\
0.99 \\
1.41 \\
0.83\end{array}$ & $\begin{array}{l}0.89 \\
1.12 \\
0.61\end{array}$ & $\begin{array}{l}1.10 \\
1.77 \\
1.12\end{array}$ & 0.010 \\
\hline $\begin{array}{c}\text { T stage } \\
\text { T1 } \\
\text { T2 } \\
\text { T3 } \\
\text { T4 }\end{array}$ & $\begin{array}{l}\text { REF } \\
1.00 \\
1.13 \\
1.30\end{array}$ & $\begin{array}{l}0.82 \\
0.92 \\
1.08\end{array}$ & $\begin{array}{l}1.23 \\
1.38 \\
1.57\end{array}$ & $<0.001$ \\
\hline $\mathrm{N}+$ disease & 1.31 & 0.91 & 1.88 & 0.147 \\
\hline $\begin{array}{c}\text { Margin } \\
\text { R0 } \\
\text { R1 } \\
\text { R2 }\end{array}$ & $\begin{array}{l}\text { REF } \\
1.11 \\
1.97\end{array}$ & $\begin{array}{l}0.98 \\
1.59\end{array}$ & $\begin{array}{l}1.25 \\
2.43\end{array}$ & $<0.001$ \\
\hline $\begin{array}{l}\text { Grade } \\
\quad \text { Low } \\
\text { Intermediate } \\
\quad \text { High }\end{array}$ & $\begin{array}{l}\text { REF } \\
1.26 \\
2.50\end{array}$ & $\begin{array}{l}1.06 \\
2.22\end{array}$ & $\begin{array}{l}1.50 \\
2.80\end{array}$ & $<0.001$ \\
\hline Chemotherapy & 1.40 & 1.21 & 1.62 & $<0.001$ \\
\hline Radiation therapy & 0.88 & 0.79 & 0.99 & 0.033 \\
\hline
\end{tabular}

* Patients with missing or unknown data excluded

HR: hazard ratio; CI: confidence interval; Ref: reference value; $\mathrm{N}+$ : node positive; R0: negative microscopic margins, R1: positive microscopic margins; R2: positive gross margins 